\title{
Analisis Total Quality Management (TQM) Terhadap Kinerja Dan Kepuasan Karyawan PT. Nagai Plastic Indonesia
}

\author{
Johan K. Runtuk ${ }^{1}$, Lina Hermawan ${ }^{2}$ \\ 1,2 Faculty of Engineering, Industrial Engineering Department, President University \\ Jl. Ki Hajar Dewantara \\ Kota Jababeka,Cikarang, Bekasi - Indonesia 17550 \\ Email: ${ }^{1}$ johan.runtuk@president.ac.id, ${ }^{2}$ linahermawan48@gmail.com
}

\begin{abstract}
ABSTRAK
Total Quality Management (TQM) adalah pendekatan yang dapat menunjang suatu perusahaan untuk dapat meningkatkan berbagai aspek di perusahaan seperti kinerja karyawan, kualitas produk dan layanan, dan lainlain. Penelitian dilakukan untuk mengetahui terkait pengaruh Total Quality Management (TQM) terhadap kinerja karyawan dan kepuasan karyawan di PT. Nagai Plastic Indonesia yang mungkin dapat menjadi acuan dalam pengambilan keputusan manajemen guna meningkatkan kualitas produk maupun pelayanan. Metode yang digunakan dalam penelitian ini adalah dengan menggunakan metode SEM-PLS yang berfungsi untuk dapat mengetahui nilai pengaruh Total Quality Management (TQM) terhadap kinerja karyawan maupun kepuasan karyawan sehingga dapat menjadi tolak ukur manajemen puncak dalam menigkatkan kualitas produk dan pelayanan perusahaan. Hasil analisa dengan menggunakan metode yang telah di tentukan adalah adanya pengaruh positif dan signifikan antara Total Quality Management (TQM) terhadap kinerja karyawan dan kepuasan karyawan. Penelitian ini menunjukkan pentingnya penerapan TQM, khususnya dalam industri manufaktur, yang secara langsung dapat meningkatkan kinerja dan kepuasan karyawan. Dalam jangka panjang, hal ini juga akan meningkatkan kepuasan pelanggan.
\end{abstract}

Kata kunci: Total Quality Management, kinerja karyawan, kepuasan karyawan, SEM-PLS

\section{ABSTRACT}

Total Quality Management (TQM) is an approach that can support a company to improve various aspects of the company, such as employee performance, product and service quality, and others. The study was conducted to determine the effect of Total Quality Management (TQM) on employee performance and employee satisfaction at PT. Nagai Plastic Indonesia, which might be a reference in management decisions to improve product and service quality. The method used in this study is to use the SEM-PLS method that serves to determine the effect of Total Quality Management (TQM) on employee performance and employee satisfaction to be a benchmark of top management in improving the quality of company products and services. The findings show a positive and significant effect between Total Quality Management (TQM) on employee performance and employee satisfaction. This study shows the importance of implementing TQM, especially in the manufacturing industry, which can directly improve employee performance and satisfaction. In the long run, this will also increase customer satisfaction.

Keywords: Total Quality Management, Employee Performance, Employee Satisfaction, SEM-PLS

\section{Pendahuluan}

Perkembangan teknologi yang kian pesat menjadikan persaingan ketat bagi perusahaan dalam menghasilkan produk yang bermutu. Berbagai pendekatan telah diciptakan untuk menunjang kualitas produk perusahaan, salah satunya yaitu pendekatan dengan praktik Total Quality Management (TQM). TQM merupakan aktivitas yang secara terus menerus pada peningkatan kualitas produk agar sesuai dengan standar kualitas dari masyarakat yang dilayani (Nasution, 2015). Dengan menerapkan teknik TQM, diharapkan dapat membantu meningkatkan kepuasan konsumen, kepuasan karyawan, dan produktivitas organisasi. TQM dilakukan secara terus menerus dalam kualitas produk sesuai dengan standar kualitas yang diinginkan konsumen.

Kepuasan karyawan merupakan keadaan emosional yang menyenangkan akibat dari penilaian pekerjaan seseorang sebagai mencapai atau memfasilitasi pencapaian nilai pekerjaan seseorang. Kepuasan karyawan adalah elemen dasar dalam model TQM. Kepuasan karyawan dianggap penting karena sifatnya asosiasi yang mapan dengan berbagai hasil organisasi, seperti kinerja karyawan (Siengthai dan Pila-Ngarm, 2016). Kepuasan karyawan merupakan bagian dari TQM yang berpengaruh terhadap kinerja karyawan. 
Kinerja karyawan merupakan kesediaan seseorang atau kelompok untuk melakukan sesuatu kegiatan dan menyempurnakannya sesuai dengan tanggung jawab dengan hasil yang diharapkan (Sinambela, 2016). Kinerja karyawan menentukan keberhasilan suatu kebijakan, khususnya untuk mengetahui kebijakan tersebut berlaku secara efisien dan efektif atau tidak. Seluruh aktivitas dalam lingkungan perusahaan diukur dari sisi akuntabilitas kinerjanya, baik dari sisi kinerja individu, kinerja unit kerja, dan kinerja perusahaan secara keseluruhan.

PT. Nagai Plastic Indonesia merupakan salah satu perusahaan manufaktur yang telah menerapkan TQM dalam menjalankan roda bisnisnnya. Namun dalam perjalanannya, terdapat permasalahan dalam penerapan TQM didalam manajemen perusahaan yang mempengaruhi kinerja dan perusahaan sehingga manajemen ingin mengetahui seberapa besar pengaruh TQM terhadap kinerja dan kepuasan karyawan.

\section{Metode}

Penelitian ini menggunakan metode survei. Sugiyono (2017) mengatakan bahwa metode penelitian adalah pendekatan ilmiah untuk mendapatkan data untuk tujuan serta kegunaan tertentu. Tahapan penelitian ini aadlah:

\section{Tahap Pengambilan Sampel}

Pada penelitian ini penentuan sampel menggunakan simple random sampling. Sugiyono (2017) mengatakan bahwa simple random sampling merupakan pengambilan sampel dari suatu populasi yang dilakukan dengan acak tanpa mempertimbangkan strata dalam populasi tersebut.

\section{Tahap Pengumpulan Data}

Penelitian ini menggunakan kuesioner untuk pengumpulan data. Sugiyono (2017) menjelaskan bahwa kuesioner adalah teknik pengumpulan data dengan cara memberikan seperangkat pernyataan tertulis kepada responden untuk diisi.

Kuesioner instrumen penelitian disusun berdasarkan kajian teori yang relevan. Selanjutnya dipilih kisi-kisi instrumen penelitian yang kemudian disusun menjadi butir-butir pernyataan. Adapun Angket atau kuesioner menggunakan skala Likert, dapat di lihat pada tabel 1.

Tabel 1. Skala Likert Jawaban Responden

\begin{tabular}{|c|c|c|c|}
\hline No & Alternatif Jawaban & $\begin{array}{c}\text { Skor Nilai } \\
\text { Positif }\end{array}$ & $\begin{array}{c}\text { Skor Nilai } \\
\text { Negatif }\end{array}$ \\
\hline 1 & Selalu (SL) & 5 & 1 \\
\hline 2 & Sering (SR) & 4 & 2 \\
\hline 3 & Tidak Menjawab (TM) & 3 & 3 \\
\hline 4 & Jarang (JR) & 2 & 4 \\
\hline 5 & Tidak pernah (TP) & 1 & 5 \\
\hline
\end{tabular}

3. Tahap Analisa Data

a. Statistik Deskriptif

Statistik deskriptif bertujuan untuk menganalisis data berdasarkan data dari jawaban responden, khususnya data demografi responden.

b. Metode Analisa Data Partial Least Squares (PLS)

Metode analisis data yang digunakan adalah Structural Equation Modeling (SEM) dengan teknik analisis Partial Least Squares (PLS) yang terdiri dari inner model dan outer model.

c. Uji Hipotesis

Hasil uji hipotesis TQM terhadap kinerja karyawan dan TQM terhadap kepuasan karyawan diperoleh dari nilai standardized loading factor dengan $p$-values lebih kecil dari alpha $(\alpha)=0,05$ ).

d. Uji R-Square

Hasil Uji $R$-Square atau koefisien determinan TQM terhadap kinerja karyawan dan TQM terhadap kepuasan karyawan diperoleh dari hasil $R$-Square dikalikan dengan 100. 


\section{Hasil dan Pembahasan}

\subsection{Deskripsi Data Hasil Analisis}

\subsubsection{Data Karakteristik Responden Penelitian}

Reponden dalam penelitian ini berjumlah 80 karyawan di PT Nagai Plastic Indonesia. Data karakteristik responden berdasarkan jenis kelamin ditunjukkan pada tabel 2 .

Tabel 2. Jenis Kelamin Responden

\begin{tabular}{|l|l|c|c|c|c|}
\hline \multicolumn{2}{|c|}{} & Frequency & Percent & Valid Percent & $\begin{array}{c}\text { Cumulative } \\
\text { Percent }\end{array}$ \\
\hline \multirow{3}{*}{ Valid } & Laki-laki & 28 & 35.0 & 35.0 & 35.0 \\
\cline { 2 - 6 } & Perempuan & 52 & 65.0 & 65.0 & 100.0 \\
\cline { 2 - 6 } & Total & 80 & 100.0 & 100.0 & \\
\hline
\end{tabular}

Berdasarkan tabel 2 di atas menunjukkan bahwa responden perempuan sebanyak 52 orang (65\%). Responden laki-laki sebanyak 50 orang (35\%). Dengan demikian, sebagian besat karyawan di PT Nagai Plastic Indonesia berjenis kelamin perempuan.

Tabel 3 menunjukkan karakteristik responden berdasarkan usianya.

Tabel 3. Usia Responden

\begin{tabular}{|l|l|c|c|c|c|}
\hline \multicolumn{2}{|c|}{} & Frequency & Percent & Valid Percent & $\begin{array}{c}\text { Cumulative } \\
\text { Percent }\end{array}$ \\
\hline \multirow{4}{*}{ Valid } & $20-30$ Tahun & 35 & 43.8 & 43.8 & 43.8 \\
\cline { 2 - 6 } & $31-40$ Tahun & 30 & 37.5 & 37.5 & 81.3 \\
\cline { 2 - 6 } & $41-50$ Tahun & 15 & 18.8 & 18.8 & 100.0 \\
\cline { 2 - 6 } & Total & 80 & 100.0 & 100.0 & \\
\hline
\end{tabular}

Tabel 3 di atas menunjukkan karyawan di PT Nagai Plastic Indonesia memiliki umur 20 - 30 tahun sebanyak 35 orang (43,8\%); umur 31 - 40 tahun sebanyak 30 orang (37,5\%); dan umur 41 - 50 tahun sebanyak 15 orang $(18,8 \%)$. Dengan demikian berdasarkan usia atau umur, karyawan di PT Nagai Plastic Indonesia sebagian besar memiliki umur 20 - 30 tahun sebanyak 35 orang $(43,8 \%)$.

Karakteristik responden berdasarkan tingkat pendidikan karyawan di PT Nagai Plastic dapat dilihat pada tabel 4.

Tabel 4. Tingkat Pendidikan Responden

\begin{tabular}{|l|l|c|c|c|c|}
\hline \multicolumn{2}{|c|}{} & Frequency & Percent & Valid Percent & $\begin{array}{c}\text { Cumulative } \\
\text { Percent }\end{array}$ \\
\hline \multirow{3}{*}{ Valid } & SMA/SMK & 53 & 66.3 & 66.3 & 66.3 \\
\cline { 2 - 6 } & D3 & 16 & 20.0 & 20.0 & 86.3 \\
\cline { 2 - 6 } & S1 & 8 & 10.0 & 10.0 & 96.3 \\
\cline { 2 - 6 } & S2 & 3 & 3.8 & 3.8 & 100.0 \\
\cline { 2 - 6 } & Total & 80 & 100.0 & 100.0 & \\
\hline
\end{tabular}

Tabel 4 menunjukkan tingkat pendidikan SMA atau SMK sebanyak 53 orang (66,3\%); D3 sebanyak 16 orang (20,2\%); S1 sebanyak 8 orang (10\%); dan S2 sebanyak 3 orang $(3,8 \%)$. Dengan demikian, berdasarkan tingkat pendidikan karyawan di PT Nagai Plastic didominasi oleh pendidikan SMA atau SMK sebanyak 53 orang (66,3\%).

Karakteristik responden berdasarkan lama bekerja dapat dilihat pada tabel 5 .

Tabel 5. Lama Bekerja Responden

\begin{tabular}{|l|l|c|c|c|c|}
\hline \multicolumn{2}{|c|}{} & Frequency & Percent & Valid Percent & $\begin{array}{c}\text { Cumulative } \\
\text { Percent }\end{array}$ \\
\hline Valid & $1-5$ tahun & 32 & 40.0 & 40.0 & 40.0 \\
\cline { 2 - 6 } & $6-10$ tahun & 13 & 16.3 & 16.3 & 56.3 \\
\cline { 2 - 5 } & $11-15$ tahun & 17 & 21.3 & 21.3 & 77.5 \\
\cline { 2 - 5 } & $16-20$ tahun & 10 & 12.5 & 12.5 & 90.0 \\
\cline { 2 - 6 } & Lebih dari 20 tahun & 8 & 10.0 & 10.0 & 100.0 \\
\cline { 2 - 6 } & Total & 80 & 100.0 & 100.0 & \\
\hline
\end{tabular}


Tabel 5 menunjukkan bahwa lama kerja karyawan di PT Nagai Plastic cukup bervariasi. Karyawan yang sudah bekerja selama 1 - 5 tahun sebanyak 32 orang (40\%), selama 11 - 15 tahun sebanyak 27 orang (21,3\%), selama 6 - 10 tahun sebanyak 13 orang $(16,3 \%)$, selama $16-20$ tahun sebanyak 10 orang $(12,5 \%)$, dan selama lebih dari 20 tahun sebanyak 8 orang (10\%). Dengan demikian, berdasarkan lama bekerja karyawan di PT Nagai Plastic yang paling banyak adalah karyawan yang sudah bekerja selama 1 - 5 tahun, yaitu sebanyak 32 orang (40\%).

\subsubsection{Data Hasil Kuisioner Penelitian}

Data hasil kuesioner penelitian berupa statistik deskripsi mengenai kinerja karyawan ( $\mathrm{Y} 1)$ dan kepuasan karyawan (Y2) sebagai variabel endogenous. Sedangkan Total Quality Management (TQM) (X) sebagai variabel exogenous. Model penelitian ini diadopsi dari penelitian Bouranta dkk. (2019). Pada variabel TQM terdapat lima dimensi, yaitu MKM (Manajemen Kualitas Karyawan), PKMP (Praktik Kualitas Manajemen Puncak), MP (Manajemen Proses), PPK (Pengetahuan dan Pendidikan Karyawan), dan FP (Fokus pada Pelanggan). Untuk variabel Kinerja Karyawan (KK) terdapat tiga dimensi, yaitu KL (Kualitas), KN (Kuantitas), dan KW (Ketepatan Waktu). Sedangkan variabel Kepuasan Karyawan (KP) terdapat tiga dimensi, yaitu U (Upah), P (Pekerjaan), dan RK (Rekan Kerja). Adapun hasil analisis Structural Equation Modeling (SEM) dengan teknik analisis Partial Least Squares (PLS) sebagai berikut :

\subsubsection{Analisis Standardized Loading Factor Model}

Hasil pengujian model akhir setelah membuang membuang indikator-indikator dengan nilai loading factor < 0,6 terdapat pada gambar 1 . Berdasarkan gambar 1 dapat dilihat bahwa setiap indikator memili nilai loading factor yang tinggi. Hal ini berarti bahwa indikator tersebut valid dalam mengukur variabel latennya.

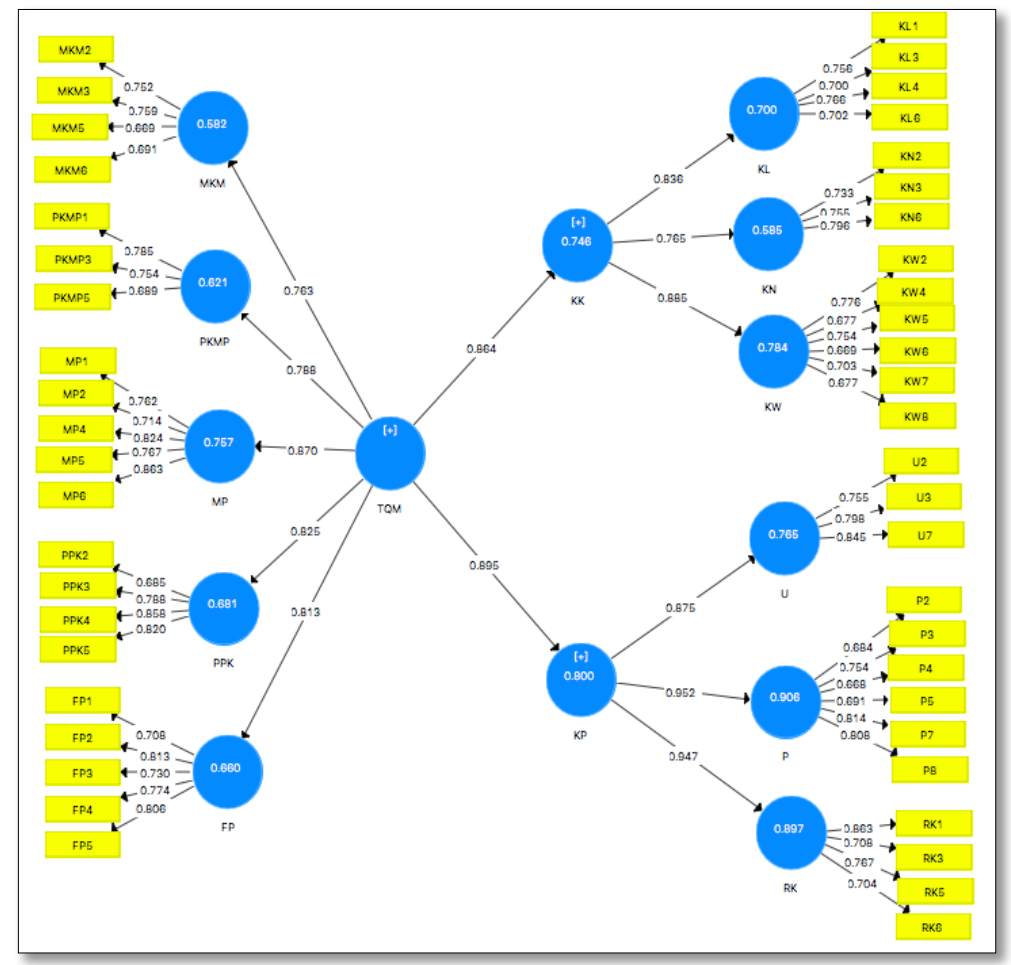

Gambar 1. Standardized Loading Factor

\subsubsection{Analisis Output T-Values Model}

Selain gambar output standardized loading factor di atas, disajikan gambar output t-values. Indikator yang valid dapat dilihat dari $t$-values $>1,96$. Adapun hasil output $\mathrm{t}$-values terdapat pada gambar 2 . Berdasarkan gambar di atas dapat dilihat bahwa semua t-values bernilai > 1,96. Hal ini menunjukkan bahwa semua indikator dapat dikatakan valid dalam mengukur variabel latennya. 


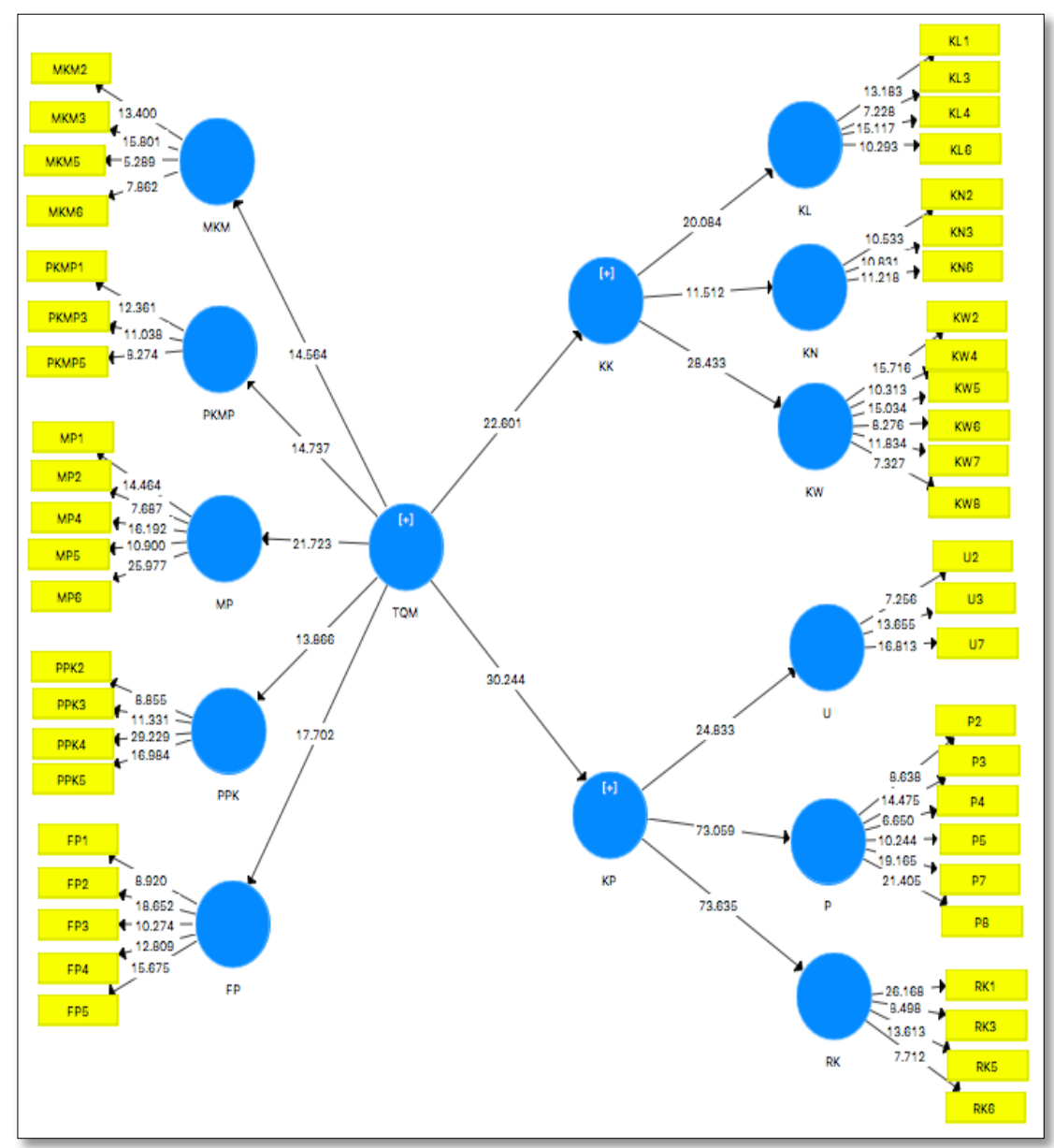

Gambar 2. T-value

\subsubsection{Uji Validitas Konvergen}

Uji validitas konvergen dilakukan dengan melihat nilai Composite Reliability (CR) dan Average Variance Extracted (AVE). Adapun hasil analisis uji konvergen validitas dapat dilihat pada tabel 6.

Tabel 5. Hasil Uji Validitas Konvergen

\begin{tabular}{|c|c|c|}
\hline Variabel & $\begin{array}{c}\text { Composite } \\
\text { Reliability (CR) }\end{array}$ & $\begin{array}{c}\text { Average Variance } \\
\text { Extracted (AVE) }\end{array}$ \\
\hline FP & 0,877 & 0,589 \\
\hline KL & 0,821 & 0,535 \\
\hline KN & 0,806 & 0,581 \\
\hline KW & 0,859 & 0,505 \\
\hline MKM & 0,810 & 0,517 \\
\hline MP & 0,891 & 0,620 \\
\hline P & 0,878 & 0,546 \\
\hline PKMP & 0,787 & 0,553 \\
\hline PPK & 0,869 & 0,625 \\
\hline RK & 0,847 & 0,582 \\
\hline$U$ & 0,842 & 0,641 \\
\hline
\end{tabular}

Berdasarkan tabel 6 menunjukkan bahwa hasil analisis uji konvergen validitas nilai Composite Reliability (CR) $>0,7$. Hasil analisis uji konvergen validitas nilai Average Variance Extracted (AVE) $>0,5$. Hal ini berarti bahwa indikator dalam variabel laten adalah valid dan reliabel. 


\subsubsection{Uji Validitas Diskriminan}

Pada penelitian ini, uji validitas diskriminan dilakukan dengan uji Fornell-Larcker. Hasil akar kuadrat dari nilai AVE tiap konstruk (nilai dengan cetak tebal) harus lebih tinggi dibandingkan nilai korelasi antar konstruk dalam suatu model. Hasil uji validitas diskriminan terdapat pada tabel di bawah ini:

Tabel 7. Hasil Uji Validitas Diskriminan

\begin{tabular}{|c|c|c|c|c|c|c|c|c|c|c|c|}
\hline & FP & KL & KN & KW & MKM & MP & P & PKMP & PPK & RK & U \\
\hline FP & $\mathbf{0 , 7 6 7}$ & & & & & & & & & & \\
\hline KL & 0,554 & $\mathbf{0 , 7 3 2}$ & & & & & & & & & \\
\hline KN & 0,558 & 0,571 & $\mathbf{0 , 7 6 2}$ & & & & & & & & \\
\hline KW & 0,628 & 0,567 & 0,501 & $\mathbf{0 , 7 1 0}$ & & & & & & & \\
\hline MKM & 0,458 & 0,583 & 0,447 & 0,617 & $\mathbf{0 , 7 1 9}$ & & & & & & \\
\hline MP & 0,528 & 0,681 & 0,539 & 0,635 & 0,615 & $\mathbf{0 , 7 8 8}$ & & & & & \\
\hline P & 0,685 & 0,746 & 0,695 & 0,694 & 0,700 & 0,772 & $\mathbf{0 , 7 3 9}$ & & & & \\
\hline PKMP & 0,632 & 0,605 & 0,457 & 0,655 & 0,615 & 0,627 & 0,718 & $\mathbf{0 , 7 4 4}$ & & & \\
\hline PPK & 0,634 & 0,546 & 0,584 & 0,607 & 0,511 & 0,672 & 0,671 & 0,486 & $\mathbf{0 , 7 9 0}$ & & \\
\hline RK & 0,709 & 0,658 & 0,640 & 0,700 & 0,643 & 0,745 & 0,649 & 0,625 & 0,719 & 0,763 & \\
\hline U & 0,547 & 0,663 & 0,645 & 0,583 & 0,621 & 0,663 & 0,731 & 0,594 & 0,599 & 0,710 & 0,800 \\
\hline
\end{tabular}

Berdasarkan Tabel 7 menunjukkan bahwa hasil akar kuadrat dari nilai Average Variance Extracted (AVE) pada FP sebesar 0,767; sedangkan AVE konstruk sebesar 0,589. KL sebesar 0,732; sedangkan AVE konstruk sebesar 0,535 . KN sebesar 0,762; sedangkan AVE konstruk sebesar 0,581. KW sebesar 0,710; sedangkan AVE konstruk sebesar 0,505. MKM sebesar 0,719; sedangkan AVE konstruk sebesar 0,517. MP sebesar 0,788; sedangkan AVE konstruk sebesar 0,620. P sebesar 0,739; sedangkan AVE konstruk sebesar 0,546. PKMP sebesar 0,744; sedangkan AVE konstruk sebesar 0,553. PPK sebesar 0,790; sedangkan AVE konstruk sebesar 0,625. RK sebesar 0,763; sedangkan AVE konstruk sebesar 0,582. U sebesar 0,800; sedangkan AVE konstruk sebesar 0,641. Dengan demikian, hasil akar kuadrat dari nilai AVE tiap konstruk (nilai dengan cetak tebal) lebih tinggi dibandingkan nilai korelasi antar konstruk dalam suatu model.

\subsubsection{Uji Hipotesis}

Hasil uji hipotesis TQM terhadap kepuasan karyawan dan TQM terhadap kinerja terdapat pada tabel 8.

Tabel 8. Hasil Uji Hipotesis

\begin{tabular}{|c|c|c|cr|}
\hline Hipotesis & $\begin{array}{c}\text { Standardized } \\
\text { Loading Factor }\end{array}$ & $p$-values & \multicolumn{2}{|c|}{ Kesimpulan } \\
\hline TQM $\rightarrow$ Kinerja Karyawan & 0,864 & 0,000 & $\begin{array}{l}\text { Pengaruh positif dan } \\
\text { signifikan }\end{array}$ \\
\hline TQM $\rightarrow$ Kepuasan Karyawan & 0,895 & 0,000 & $\begin{array}{l}\text { Pengaruh positif dan } \\
\text { signifikan }\end{array}$ \\
\hline
\end{tabular}

Berdasarkan tabel 8 menunjukkan bahwa pengaruh TQM terhadap kinerja karyawan memperoleh nilai standardized loading factor sebesar 0,864 dengan $\rho$-values sebesar 0,000. Pengaruh TQM terhadap kepuasan karyawan memperoleh nilai standardized loading factor sebesar 0,895 dengan $p$-values sebesar 0,000 (lebih kecil dari alpha $(a)=0,05)$. Dengan demikian, terdapat pengaruh positif dan signifikan TQM terhadap kinerja dan kepuasan karyawan. Adapun pengaruh yang paling besar terhadap TQM adalah kepuasan karyawan $(0,895)$.

\subsubsection{Uji R-Squares}

Hasil Uji R-Square atau koefisien determinan TQM terhadap kinerja karyawan dan TQM terhadap kepuasan karyawan dapat dilihat pada tabel 9.

Tabel 5. Hasil Uji R-Square

\begin{tabular}{|l|c|}
\hline \multicolumn{1}{|c|}{ Variabel } & R-square \\
\hline Kinerja Karyawan & 0,746 \\
\hline Kepuasan Karyawan & 0,800 \\
\hline
\end{tabular}

Berdasarkan tabel 9 menunjukkan bahwa kontribusi determinan TQM terhadap kinerja karyawan sebesar 0,746 atau $74,6 \%$ sedangkan sisanya $25,4 \%$ dipengaruhi oleh variabel di luar TQM. Kontribusi determinan TQM terhadap kepuasan karyawan sebesar 0,800 atau $80 \%$ sedangkan sisanya $20 \%$ dipengaruhi oleh variabel di luar 
TQM. Hal ini menunjukkan bahwa TQM memiliki pengaruh yang besar terhadap kinerja dan kepuasan karyawan. Namun demikian, kontribusi determinan yang lebih besar adalah TQM terhadap kepuasan karyawan sebesar 0,800 atau $80 \%$.

\subsection{Pembahasan Hasil Penelitian}

Berdasarkan hasil uji hipotesis penelitian secara empiris terdapat pengaruh TQM terhadap kinerja karyawan dan TQM terhadap kepuasan karyawan. Hal ini sesuai dengan hasil penelitian yang dilakukan oleh penelitian Bouranta dkk. (2019) hasil penelitian menunjukkan, elemen TQM seperti (a) manajemen kualitas karyawan (employee quality management), (b) praktik kualitas manajemen puncak (quality practices of top management), (c) manajemen proses (process management), (d) pendidikan dan pelatihan karyawan (employee knowledge and education) dan (e) fokus pada pelanggan (customer focus) berpengaruh terhadap kinerja yang berfokus pada pelanggan dan karyawan.

Berdasarkan hasil pembahasan penelitian diatas, hipotesis yang sebelumnya dipaparkan terbukti positif dan sudah sejalan dengan penelitian - penelitian lainnya terkait pengaruh kinerja dan kepuasan karyawan terhadap TQM yang dilakukan oleh Pratama dan Maghfiroh (2016), Sitio (2018) Suartini dkk. (2019), dan Astuti (2019).

Pada beberapa perusahaan memiliki dinamika TQM, kepuasan karyawan dan kinerja karyawan yang berbeda. Penelitian ini mungkin berguna bagi perusahaan di PT Nagai Plastic Indonesia yang dipresentasikan di perusahaan-perusahaan yang berbeda di dalam negeri. Terutama dalam memberikan kebijakan dan peraturan perusahaan terhadap karyawan.

\section{Kesimpulan}

Berdasarkan hasil penelitian ini terdapat beberapa poin yang menjawab permasalahan yang ada, antara lain :

a. Hasil temuan penelitian menunjukkan terdapat pengaruh positif dan signifikan TQM terhadap kinerja karyawan. Variabel TQM dapat menjelaskan variasi nilai kinerja karyawan sebesar $74,6 \%$.

b. Hasil temuan penelitian menunjukkan terdapat pengaruh positif dan signifikan TQM terhadap kepuasan karyawan. Variabel TQM dapat menjelaskan variasi nilai kepuasan karyawan sebesar $80 \%$.

Dengan hasil yang ada, management PT. Nagai Plastic Indonesia memiliki referensi dalam mengambil kebijakan guna meningkatkan kinerja dari perusahaan.

Penelitian ini memiliki kekurangan karena hanya fokus pada satu perusahaan. Penelitian selanjutnya dapat melanjutkan penelitian ini pada sampel yang lebih besar dan mencakup beberapa perusahaan untuk mendapatkan generalisasi yang lebih kuat. Penelitian selanjutnya dapat menambahkan wawancara untuk memperdalam hasil penelitian kuantitatif dari survey. Variabel-variabel yang mempengaruhi kesuksesan penerapan TQM juga perlu untuk dikaji dalam penelitian selanjutnya.

\section{Daftar Pustaka}

1. Astuti, T.B (2019). Pengaruh Teknik Total Quality Management terhadap Kinerja Manajerial dengan Sistem Pengukuran Kinerja dan Sistem Penghargaan serta Perilaku Manajer sebagai Variabel Moderating, Jurnal Ilmu Manajemen dan Akuntansi, 7, 1, 46-57.

2. Bouranta, N., Psomas, E., Suárez-Barraza, Manuel F., dan Jaca, Carmen (2019). The key factors of total quality management in the service sector: a cross-cultural study, Benchmarking: An International Journal, 26, 3, 893-921.

3. Nasution, M. N. (2015). Manajemen Mutu Terpadu (Total Quality Management), Jakarta: Ghalia Indonesia.

4. Pratama, Abdul A. N dan Maghfiroh, Fira N (2016). Pengaruh Total Quality Management (TQM) terhadap Kinerja Karyawan di BMT Taruna Sejahtera Ungaran, Jawa Tengah, Jurnal Muqtasid, 7, 1, 93-117. 
5. Siengthai, S. \& Pila-Ngarm, P. (2016), The interaction effect of job redesign and job satisfaction on employee performance, Evidence-Based HRM: a Global Forum for Empirical Scholarship, 4, 2, 162-180.

6. Sinambela, L. P (2016). Manajemen Sumber Daya Manusia, Jakarta: Bumi Aksara.

7. Sitio V. S. S. (2018). Pengaruh Total Quality Management (TQM) dan Gaya Kepemimpinan Terhadap Kinerja Karyawan Pada PT. Pelita Air Service. Journal of Management and Business Review. 15, 2, 196 - 218.

8. Suartini N. L. K., Gama A. W. S., \& Astiti N. P. Y. (2019). Effect of Productive Assets Earnings and Third Party Funds On Operational Performance Lembaga Perkreditan Desa (LPD) In Badung District. The 9th International Conference Rural Research and Planning Group, 287 - 294.

9. Sugiyono (2017). Metode Penelitian Kuantitatif, Kualitatif, dan R\&D, Bandung: CV Alfabeta. 